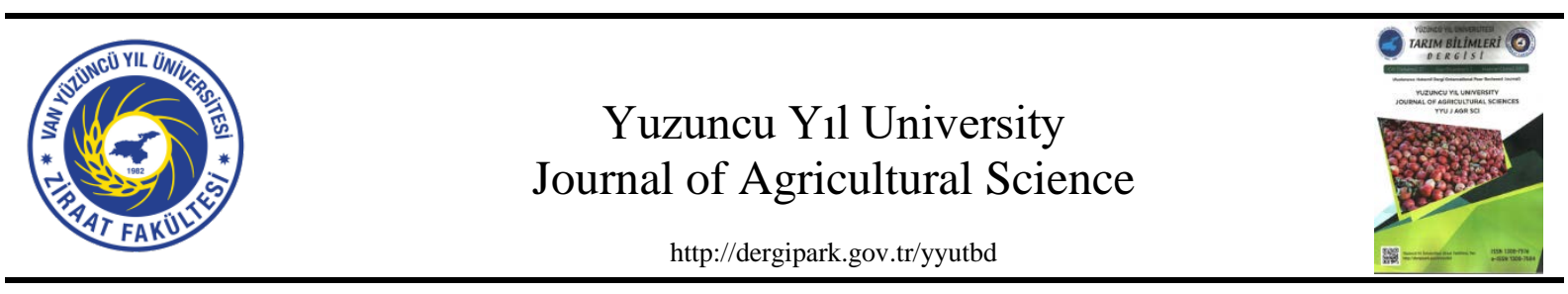

Research Article (Araştırma Makalesi)

Changes in Basic Soil Physical Properties of Agrochernozyems Under No-till Conditions
Ruslan SULEYMANOV ${ }^{*}$, Sergey ZAYKIN², Azamat SULEYMANOV ${ }^{3}$, Evgeny ABAKUMOV ${ }^{4}$, Jakub KOSTECKí ${ }^{5}$

1,2,3 Ufa Institute of Biology, Ufa Federal Research Center, Russian Academy of Sciences, Ufa, Russia

${ }^{4}$ Saint Petersburg State University, Faculty of Biology, Saint Petersburg, Russia

${ }^{5}$ University of Zielona Góra, Institute of Environmental Engineering, Zielona Góra, Poland

\author{
${ }^{1}$ https://orcid.org/0000-0002-7754-0406 ${ }^{2}$ https://orcid.org/0000-0002-0873-5373 ${ }^{3}$ https://orcid.org/0000-0001-7974-4931 \\ ${ }^{4}$ https://orcid.org/0000-0002-5248-9018 5https://orcid.org/0000-0002-4231-1080 \\ *Corresponding author e-mail: soils@mail.ru
}

\section{Article Info \\ Received: 18.06.2020 \\ Accepted: 23.11.2020 \\ Online Published 31.12.2020 \\ DOI: $10.29133 /$ yyutbd.754479}

\section{Keywords}

Agrochernozem,

No-Till,

Soil physical properties.

\begin{abstract}
Agriculture is one of the leading branches of the economy in the Republic of Bashkortostan (Russia). Long-term agricultural use of land with the use of plowing has led to a decrease in the thickness of humus-accumulation horizon of soils, reduction of organic matter and nutrients. There is also a deterioration in water-physical properties, the development of water and wind erosion, and a decrease in productivity. Recently, the use of soil conservation farming systems has started, including the use of No-till system. This study presents the results of assessment of physical properties of agrochernozems under conditions of No-ill use. The physical properties of the soil, such as bulk density, humidity, temperature, structural and aggregate composition, were studied using methods and tools accepted in soil science. It is shown that in the upper soil layer $(0-20 \mathrm{~cm})$ there is an accumulation of soil moisture, the values of capillary and total moisture capacity, as well as bulk density are approach to the values of nature soil and are optimal for the growth and development of agricultural crops. Structural and aggregate composition is characterized by excellent aggregate state with their excessively high resistance to damaging effects of water. However, in a single case, the soil density increases to a depth of $45 \mathrm{~cm}$. This fact was caused by the impact of heavy agricultural machinery. The declining of soil density can be achieved by treating it with a special bioorganic agent and growing perennial grasses.
\end{abstract}

\title{
Toprak İşlemesiz Koşullar Altında Agrochernozyemlerin Temel Fiziksel Özelliklerindeki Değişimler
}

\section{Makale Bilgileri}

Geliș: 18.06 .2020

Kabul: 23.11.2020

Online Yayınlanma 31.12.2020

DOI: $10.29133 /$ yyutbd.754479

\section{Anahtar kelimeler}

Agrokernozem,

İşlemesiz toprak, Fiziksel toprak özellikleri.
Öz: Tarım, Başkurdistan Cumhuriyeti'nde (Rusya) ekonominin önde gelen dallarından biridir. Toprağın uzun süreli tarımsal kullanımı, toprağın humus birikimi horizon kalınlığının azalmasına, organik madde ve besin maddelerinin azalmasına neden olmaktadır. Ayrıca su-fiziksel özelliklerinde bir bozulma, su ve rüzgar erozyonunun artması ve verimlilikte bir azalma söz konusu olmaktadır. Son zamanlarda, toprak işlemesiz sistem kullanımı da dahil olmak üzere, toprak korumalı tarım sistemlerinin kullanımı başlamıştır. $\mathrm{Bu}$ çalışmada agrokernozemlerin fiziksel özelliklerinin toprak işlemesiz sistem kullanımı koşulları altında değerlendirilmesinin sonuçlarını sunmaktadır. Toprağın kütle yoğunluğu, nem, sıcaklık, yapısal ve agrega bileşimi gibi fiziksel özellikleri, 
toprak biliminde kabul edilen yöntemler ve araçlar kullanılarak incelenmiştir. Üst toprak tabakasında $(0-20 \mathrm{~cm})$ toprak nemi birikiminin olduğu, kılcal ve toplam nem kapasitesi değerlerinin yanı sıra kütle yoğunluğunun doğadaki toprağının değerlerine yaklaştığı ve tarımsal ürünlerin büyümesi ve gelişmesi için en uygun olduğu gösterilmiştir. Yapısal ve agrega bileşimi, suyun zararlı etkilerine aşırı derecede yüksek dirençleri ile mükemmel agrega hali ile karakterize edilir. Ancak tek bir durumda toprak yoğunluğu $45 \mathrm{~cm}$ derinliğe kadar çıkmaktadır. Bu gerçek, ağır tarım makinelerinin etkisinden kaynaklanmaktadır. Toprak yoğunluğunun azalması, özel bir biyoorganik ajan ile muamele edilerek ve çok yıllık otlar yetiştirilerek sağlanabilir.

\section{Introduction}

Nowadays about $25 \%$ of the Earth's land surface and $40 \%$ of agricultural land are faced to intensive degradation. The environmental impacts of land degradation are extensive and include irreversible losses of soil, deteriorating water quality, reducing biodiversity, and deterioration of numerous ecosystem services. The global costs of land degradation in agriculture alone are approaching $\$ 500$ billion. As a result, the United Nations General Assembly adopted a program in 2015 aimed at combating desertification and reclaiming degraded land, in which sustainable land management is one of the proposed ways of implementing agricultural practices (Pacheco et al., 2018; Begum Nasir Ahmad et al., 2020).

One of the most important land degradation processes in the world is soil erosion, which is considered a major threat to food security and human health. Ultimately, this will lead to a complete loss of the surface layer and, consequently, land fertility (Govers et al., 2014; Luetzenburg et al., 2020). Research shows that land-use change can transform resilient agro-ecosystems into highly degraded ones in a relatively short period (Vanwalleghem et al., 2017). Erosion processes also correlate with slopes, height, precipitation, temperature, soil structure, and the degree of insolation (Nowak and Schneider, 2017; Bednáŕ and Šarapatka, 2018). The political conditions and socioeconomic level of development in the region play an important role, which determines the structure and culture of land use, the size of cultivated fields, the choice of crops, the norms and quality of fertilizers used (Zambon et al., 2017; Bajocco et al., 2018; Baude et al., 2019; Vávra et al., 2019; Smetanová et al., 2019).

It is known that erosion leads to a negative impact on the quality of agricultural soils, changes in chemical and biochemical properties, a decrease in the content of organic substances and basic nutrients, and changes in the total content of organic carbon content of humic acids and C:N ratio, levels decreases enzymatic and microbiological activity (Park et al., 2014; Sarapatka et al., 2018). At the same time, there is a transformation of temporal and spatial dynamics agrophysical properties, first of all, erosion and accumulative processes increase, power of humus accumulative horizon decreases (Gabbasova et al., 2016), soil bulk density and porosity change (Gurbanov, 2010), the soil structure becomes degraded and water resistance become essentially reduced (Travnikova et al., 2010; Babaev et al., 2015) and the hydrological regime become disrupted (Wilson et al., 2020).

Recently, various soil-conservative land-use systems have been widely used in world agricultural practice, among which No-till is leading (Skaalsveen et al., 2020). A change from conventional tillage to No-till can improve soil carbon sequestration and resilience to erosion (Ferreira et al., 2020), and there is an increase in mobile phosphorus (Li et al., 2019), nitrogen and potassium (Sithole et al., 2019), the water-holding capacity of the soil and the rate of infiltration increase (Nunes et al., 2018), the structure of the soil improves and the biological activity increases (Piazza, 2020).

Agriculture is one of the leading branches of the economics in the Republic of Bashkortostan (Russia). Agricultural lands occupy 50.2\% in the land fund of the area, on average 65\% of arable lands, $25 \%$ of pastures, and $9 \%$ of hayfields are represented in their composition. The diversity of natural and environmental conditions creates significant differences in the ratio of agricultural lands by natural and climatic zones. Thus, the areas of the Northern and Southern forest-steppe (73.4 and $71.3 \%$, respectively), then the Northeast forest-steppe (69.4\%) and the Pre-Urals steppe (67.5\%) are the most open. In the mountainous and forest zone, arable land occupies $25.7 \%$ of the area, in the plain-steppe Trans-Urals - 24.6\%. The high degree of plowing and natural conditions under the 
combined influence of economic activity create conditions for the development of both water and wind erosion of soils in almost all regions of the republic, 28\% of the Republic's area (4030.4 thousand ha) is subject to erosion, including 55\% (3970 thousand ha) of agricultural land, including 2451 thousand ha of arable land (57\% of arable land), and another 2.7 million ha of land are erosive dangerous (Khaziev, 2012).

According to the scheme of soil-agro ecological zoning of agricultural lands of Russia, the territory of the plain part of the Trans-Ural region of the Republic belongs to the steppe zone (B-VI) of intensive grain farming and meat and milk cattle breeding with a predominance of high humus soils of insufficient moisture supply (Vermic Chernozems, Calcic Chernozems, Gley Chernozems), eroded and an exposed to wind erosion deflated, with a spread in hydromorphic and semi-hydromorphic conditions of saline and Haplic Solonetz Albic soils and complexes with Haplic Solonetz Albic soils (Pankova and Novikova, 2000).

To date, there is an alarming environmental situation in the Trans-Urals related to land use violations. As a result of the development of the nature lands in the 50s, the traditional system of environmental management with animal husbandry as the main branch of the economy was deformed. Steppes in Khaibullinsky, Baimaksky and Abzelilovsky districts were the most plowed and eroded. The plowing soil warms up strongly during the daytime insolation, which leads to their drying out and intense water loss. The humus in the soil is highly mineralized. Annual losses of humus reach one ton per hectare. Physical properties of soils and their structural condition deteriorate, the soil lumpiness of arable land increases, and an increase in soil density at a depth of one meter can be recorded (Khaziev, 1997).

Recently there has been a tendency to mainstream soil-conservation tillage systems into agricultural practice in the republic. Especially No-Till technology has been widely developed in the Trans-Urals region (Gabbasova et al., 2018). It was widely known that the application of No-Till technology first affects the physical properties of soils. Changes in soil structure (de Paula et al., 2020) and bulk density occur (Gürsoy and Türk, 2019). Some authors (Yin et al., 2020) have shown that NoTill and mulching optimize soil temperature and help maintain soil moisture. Therefore, the purpose of our research was to evaluate the physical properties (density, humidity, temperature, structural and aggregate composition) of agronomic Calcic Chernozem under conditions of No-Till technology.

\section{Material and Methods}

The researches to study a physical properties of soils were conducted in the first decade of September 2019 in the territory of the agricultural production cooperative (APC) Krasnaya Bashkiriya, which is located in the Abzelilovsky district of the Republic of Bashkortostan within the plain TransUrals (Fig 1). The APC is located in the steppe zone. The relief is a low plain. The climate is warm and dry. The sum of active temperatures is $2000-2200^{\circ} \mathrm{C}$, average annual air temperature approximately $2^{\circ} \mathrm{C}$, average temperature in July $+18-19,5^{\circ} \mathrm{C}$, average temperature in January $-16^{\circ} \mathrm{C}$. The annual sum of precipitation is $270-350 \mathrm{~mm}$ (Kadilnikov, 1964).

The following soil pits were made on agricultural lands where No-till is used (Fig 1):

Pit 1. No-till has been used since 1991, at the time of the soil physical properties study (2019) wheat (Triticum aestivum L.) was sown but has not yet been harvested, in 2018 sunflower Helianthus annuus L.)was grown (, sunflower crop residues after harvest were shredded and left on the soil surface, perennial grasses were grown from 1991 to 2012, and since 2011 there was rotation of corn, wheat and sunflower (N 5326.642', E 58 $\left.51.663^{\prime}\right)$.

Pit 2. Control, forest belt, ordinary ash (Fraxinus excelsior L.), nature land (N 5326.636', E $\left.58^{\circ} 50.970^{\prime}\right)$.

Pit 3. No-till has been used since 2009, wheat was grown in 2019, ordinary barley (Hordeum vulgare L.) was grown in 2018, after harvesting plant residues were shredded and left on the soil surface (N 5323.545', E 58²4.420').

Pit 4. No-till has been used since 2010, peas (Pisum sativum L.) with mustard (Sinapis alba L.) were grown in 2019, wheat was grown in 2018, after harvesting plant residues were shredded and

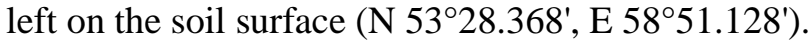


Pit 5. No-till has been used since 2010, melilótus (Melilotus albus Medik.) is grown since

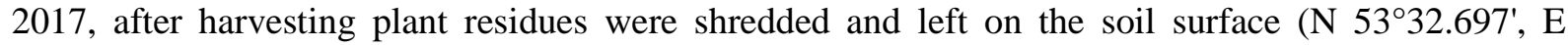
$\left.58^{\circ} 48.445^{\prime}\right)$.

In all studied agricultural lands, the seeds are sown directly using a special seed drill for Notill technology to a depth of 2-3 cm. The construction of the seeder allows for sowing with preservation of plant residues and stubble, which has been preserved on the soil surface from previous crops. An obligatory element of such seeders is a thin press wheel following a thin anchor coulter that cuts a furrow at the desired depth. Harvesting and shredding of crop residue is carried out by specialized harvesting machines for each crop.

The soil cover at all studied agricultural lands of identical and it is represented by agronomic weakly-medium eroded Calcic Chernozem (Fig. 2). The granulometric composition (was determined according to pipette method (Shein and Karpachevskii, 2007)) of the humus-accumulative horizon of soil is characterized as clay loamy texture class (sand $-21.7 \%$, silt $-47.8 \%$, clay $-30.5 \%$ ), soil reaction - neutral $\left(\mathrm{pHH}_{2} \mathrm{O}\right.$ - 6.9), the organic matter content is $38.9\left(\mathrm{~g} \mathrm{~kg}^{-1}\right.$ soil), alkaline hydrolyzable nitrogen - 166 ( $\mathrm{mg} \mathrm{kg}^{-1}$ soil) and available phosphorus - 1.9 ( $\mathrm{mg} \mathrm{kg}^{-1}$ soil) (Gabbasova et al., 2015) (Table 1).

The physical properties of soils were determined by the methods generally accepted in soil science: the bulk density (has been determined by drilling), the categories of humidity (has been determined by water saturation and further weighing), structural-aggregate composition (has been determined by gravimetrical-sieve method), and water resistance of soil aggregates (has been determined by wet sieving) (Shein and Karpachevskii, 2007). Field moisture was determined using Soil Moisture Sensor SM 150 digital field moisture meter, soil penetration was measured from the soil surface to a depth of $45 \mathrm{~cm}$ in $2.5 \mathrm{~cm}$ intervals by using Soil Compaction Meter FieldScout SC 900 equipped a metal rod with a cone (size 1/2 inch), soil temperature was measured by soil thermometer AM-6. Location map of the study area was created using Google maps service. Statistical analysis (mean, standard deviation, Student's t-test) was performed using MS Excel 2007.

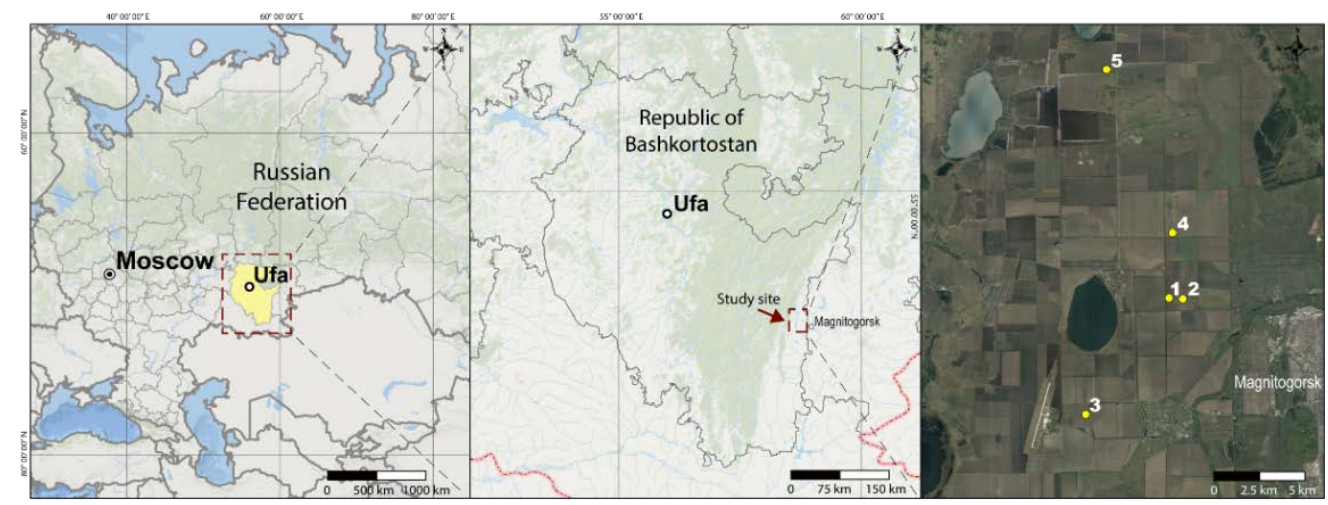

Figure 1. Map of the study area.

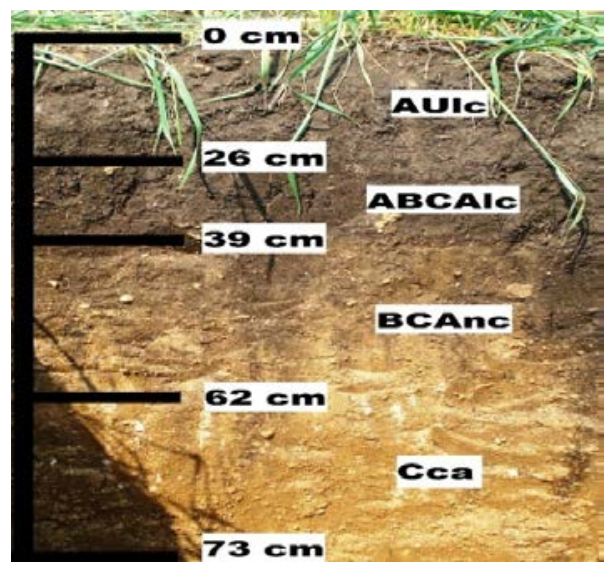

Figure 2. Soil profile of agronomic Calcic Chernozem. 
Table 1. Chemical properties of agrochernozem (averaged data) (Gabbasova et al., 2015)

\begin{tabular}{cccccc}
\hline \multirow{2}{*}{ Determination } & \multirow{2}{*}{ Unit } & AUlc 0-26 & ABCAlc 26-39 & BCAnc 39-62 & Cca 63-73 \\
\hline $\mathrm{pH} \mathrm{H}_{2} \mathrm{O}$ & \multirow{2}{*}{$\mathrm{g} \mathrm{kg}^{-1}$ soil } & $6.9 \pm 0.1$ & $7.6 \pm 0.3$ & $8.2 \pm 0.2$ & $8.2 \pm 0.1$ \\
$\mathrm{Corg}$ & $38.9 \pm 8.3$ & $22.7 \pm 1.4$ & $9.3 \pm 1.6$ & $2.1 \pm 0.4$ \\
$\mathrm{~N}$ alkaline & $\mathrm{mg} \mathrm{kg}^{-1}$ soil & $166 \pm 27.3$ & $63 \pm 18,1$ & $28 \pm 5.7$ & $11 \pm 2.1$ \\
hydrolysable & $\mathrm{mg} \mathrm{kg}^{-1}$ soil & $1.9 \pm 1.1$ & $0.8 \pm 0.2$ & $0.4 \pm 0.2$ & $0.3 \pm 0.1$ \\
$\mathrm{P}_{2} \mathrm{O}_{5}$ available & & mean \pm standard deviation, $\mathrm{n}=6$ & & \\
\hline
\end{tabular}

\section{Results and Discussion}

The field surveys were carried out at the end of the growing season (the amount of precipitation for this period $-290 \mathrm{~mm}$ ), as the investigated agricultural lands were located in comparable landscape and climatic conditions then soil profiles were characterizes by approximately one level of moisture. Therefore, the penetration resistance in the field condition was determined without measuring humidity.

Determination of penetration resistance using penetrometer has shown that in almost all the fields studied, the values of resistance to penetration into the soil of a metal rod with a cone at the end to a depth of $20 \mathrm{~cm}$ are within the limits of normal (0-1379 kPa, Pit 3) or average growth of the root system (1379-2068 kPa, Pits 4 and 5). With depth, these indicators increase, which is generally characteristic of nature soils (Pit 2) (Fig. 3). At Pit 1, with a depth of $7.5 \mathrm{~cm}$, there is a sharp increase in resistance values to $\sim 4000-4500 \mathrm{kPa}$, the values of which are within the limits of bad (2068 and more $\mathrm{kPa}$ ) root system growth and are preserved for the entire studied profile depth (up to $45 \mathrm{~cm}$ ). This compaction can be the result of prolonged exposure to heavy agricultural machinery. Some works also note compaction in the No-till system (Gao et al., 2016; Ferreira et al., 2020) and it is particularly strong in arid climatic conditions (Radford et al., 2007; Lin \& Chen, 2016).

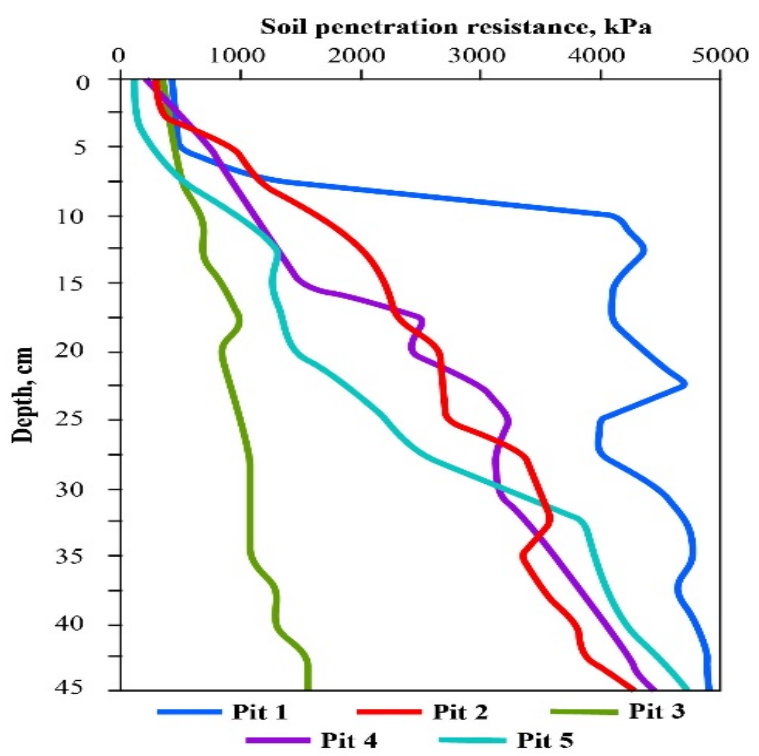

Figure 3. Vertical distribution of soils penetration resistance under No-till conditions.

At the time of the survey, the lowest temperature in the upper surface of topsoil $(0-20 \mathrm{~cm})$ soil layer was observed in the area with unharvested wheat (Pit 1), the maximum values - in fields where crops have already been harvested (Pits 4 and 5). The temperature difference in these areas was $4.5^{\circ} \mathrm{C}$ (Table 2). We note that soil temperature is an important agro-meteorological indicator that is necessary for the effective activity of agricultural practices. The most interesting is the estimation of soil temperature in the upper layers of the soil profile where plant roots grow (Huang et al., 2020). Plant cover also has an impact on soil temperature and humidity. Of course, long spring-summer- 
autumn studies with the use of special equipment are necessary to study their seasonal fluctuations, as each period of the growing year has its specifics of soil-plant system functioning (Ni et al., 2019).

Table 2. Water-physical properties of soils under No-till conditions

\begin{tabular}{|c|c|c|c|c|c|}
\hline \multirow{2}{*}{$\begin{array}{l}\text { Depth, } \\
\text { cm }\end{array}$} & \multirow{2}{*}{$\begin{array}{c}\text { Temperature, } \\
\mathrm{C}^{\circ}\end{array}$} & \multirow{2}{*}{$\begin{array}{l}\text { Bulk density, } \\
\mathrm{g} \mathrm{cm}^{-3}\end{array}$} & \multirow{2}{*}{$\begin{array}{c}\text { Field } \\
\text { moisture (gravimetric), \% }\end{array}$} & \multicolumn{2}{|c|}{ Moisture content, \% } \\
\hline & & & & Capillary & Total \\
\hline & & & Pit 1 & & \\
\hline $0-10$ & \multirow{2}{*}{$8.9 \pm 0.7$} & $1.16 \pm 0.10$ & $39.3 \pm 5.4$ & $42.2 \pm 11.5$ & $50.2 \pm 11.1$ \\
\hline $10-20$ & & $1.28 \pm 0.04$ & $29.2 \pm 3.4$ & $38.6 \pm 2.4$ & $42.6 \pm 1.3$ \\
\hline & & & Pit 2 & & \\
\hline $0-10$ & \multirow{2}{*}{$10.1 \pm 0.8$} & $1.09 \pm 0.04$ & $16.9 \pm 2.9$ & $47.3 \pm 3.5$ & $65.4 \pm 3.2$ \\
\hline $10-20$ & & $1.24 \pm 0.04$ & $20.0 \pm 6.9$ & $37.9 \pm 1.8$ & $46.7 \pm 0.6$ \\
\hline & \multirow{4}{*}{$11.2 \pm 0.07$} & & Pit 3 & & \\
\hline $0-10$ & & $1.13 \pm 0.02$ & $37.2 \pm 1.3$ & $43.4 \pm 1.1$ & $54.5 \pm 1.3$ \\
\hline $10-20$ & & $1.19 \pm 0.05$ & $37.5 \pm 0.6$ & $35.8 \pm 1.0$ & $48.3 \pm 1.7$ \\
\hline & & & Pit 4 & & \\
\hline $0-10$ & \multirow{2}{*}{$13.3 \pm 0.07$} & $1.15 \pm 0.10$ & $26.5 \pm 5.9$ & $38.4 \pm 4.7$ & $49.7 \pm 7.3$ \\
\hline $10-20$ & & $1.33 \pm 0.05$ & $20.2 \pm 2.9$ & $34.5 \pm 1.7$ & $37.3 \pm 1.9$ \\
\hline & \multirow{3}{*}{$13.5 \pm 0.07$} & & Pit 5 & & \\
\hline $0-10$ & & $1.17 \pm 0.01$ & $34.2 \pm 1.9$ & $32.9 \pm 2.5$ & $46.0 \pm 2.0$ \\
\hline $10-20$ & & $1.33 \pm 0.03$ & $23.8 \pm 4.2$ & $33.0 \pm 1.0$ & $39.4 \pm 1.4$ \\
\hline \multicolumn{6}{|c|}{ mean \pm standard deviation, $\mathrm{n}=5$} \\
\hline
\end{tabular}

In the surveyed areas, the values of field moisture were significantly higher than those of nature soils, especially in the $0-10 \mathrm{~cm}$ layer (by about $10-20 \%$ ) (Table 2). At the same time, moisture content categories (capillary and total) were slightly lower than that of the nature soil, which is probably due to some increase in bulk density, but in general, these indicators are within the limits typical for soils in the region (Gabbasova et al., 2015).

The analysis of the structural and aggregate composition of the studied soils showed that the share of aggregates of the agronomically valuable range $(10-0.25 \mathrm{~mm})$ in the soils of agricultural land is $\sim 71-76 \%$ (respectively, the aggregation coefficient 2.42-4.26 at 8.62 on nature soil (t-empirical 23.2, t-critical - 3.71, $\mathrm{p} \leq 0.01)$ ) and is characterized as "excellent aggregate state", which indicates the formation of an optimal hydrological and aeration regime of agricultural plants (Fig. 4). The agronomic value of a structure is determined by its water resistance, which is calculated based on the sum of units $>0.25 \mathrm{~mm}$, obtained after ,wet” sifting. The share of water-resistance units of the studied soils was $\sim 80-90 \%$ (respectively, water-stability factor $-0.83-0.89$ at 0.93 on the nature soil (tempirical - 7.0, t-critical - 3.71, $\mathrm{p} \leq 0.01)$ )), which characterizes the structure of the soil as "excessively high" and give possibility to predict that soil will be stable to water erosion. (Fig. 5) (Shein and Karpachevskii, 2007). Some authors (Ferreira et al., 2020) note that prolonged use of No-till increased the content of organic carbon particles, mineral-bound organic substances and humic as a result of the constant flow of plant residues into the surface layers, which contributed to the increase in physical and chemical aggregation of the soil and the increase in its water content. Compared to other systems, No-till increased the electrical conductivity, cation exchange capacity, total nitrogen and total organic carbon in the uppermost soil layer (Neugschwandtner et al., 2020). 


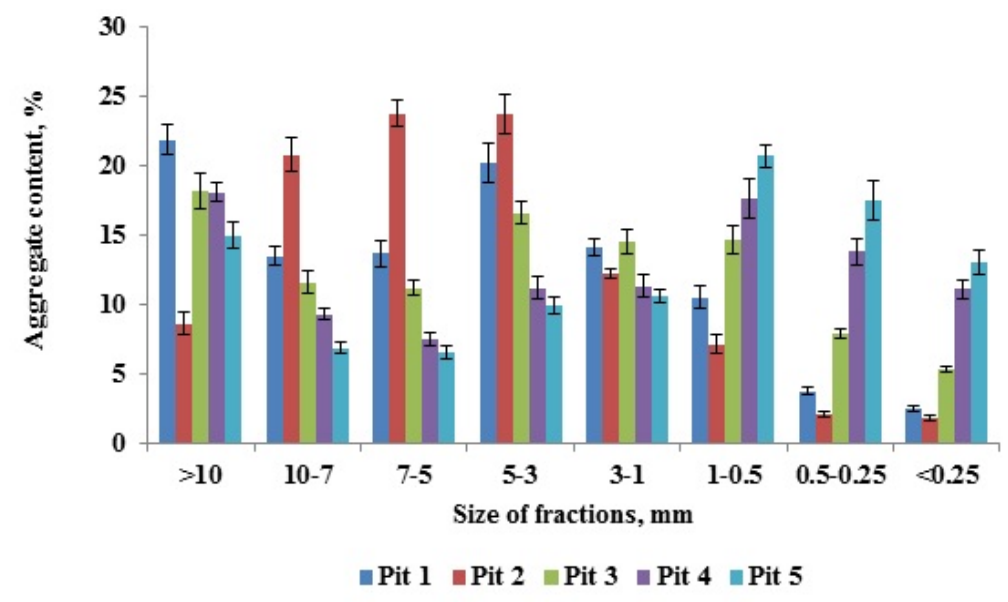

Figure 4. Structural and aggregate composition of soils in the layer of $0-20 \mathrm{~cm}$.

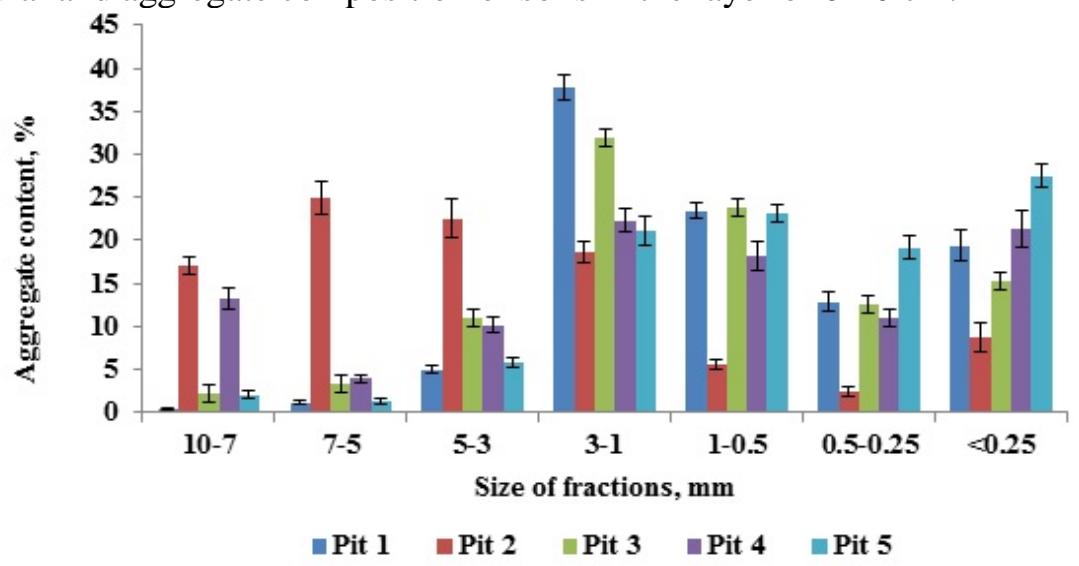

Figure 5. Water-stable aggregate fractions of soils in the layer of $0-20 \mathrm{~cm}$.

\section{Conclusions}

Long-term use of farming systems with the use of plowing, especially in the arid climate of the Trans-Urals (Russia, Republic of Bashkortostan) has led to the degradation of the soil cover. There is a development of erosion, a decrease in the thickness of humus-accumulation horizon, reduction of humus and nutrients contents, deterioration of water and physical properties in the soil which ultimately leads to a decrease in yield and economic efficiency. Therefore, many agricultural enterprises began to use soil-saving technologies, including No-till.

The studies carried out on the study of physical properties of soils in APC Krasnaya Bashkiriya (Abzelilovsky district of the Republic of Bashkortostan) showed that as a result of the switching to the use of No-till, soil moisture is preserved and increased. The values of the capillary and total moisture capacity, as well as the bulk density in the upper layer of $0-20 \mathrm{~cm}$ of agrochernozem, approach the values of nature soil.

The measurement of soil resistance to penetration of a metal rod with a cone at the end from the surface to a depth of $45 \mathrm{~cm}$ showed that the soil density indicators correspond to the nature lands and are within optimal limits for growth and development of agricultural plants. In one of sites, which is treated by the No-till system approximately 30 years, there is a critical level of compaction from a depth of $10 \mathrm{~cm}$, which is obviously due to the type of crops grown and the long-term impact of heavy agricultural machinery.

Structural and aggregate composition of agrochernozems in condition No-till system is characterized by excellent aggregate state with their excessively high resistance to damaging effects of water. 


\section{Acknowledgements}

The reported study was funded by Russian Foundation for Basic Research, project number 1934-90001; by Russian Scientific Foundation, project 17-16-01030 and was performed within the framework of state assignment of the Ministry of Science and Higher Education of the Russian Federation № 075-00326-19-00 on topic № AAAA-A18-118022190102-3.

Special thanks to the Prof. Dr. Ridvan Kizilkaya and Dr. Sevilay Haciyakupoğlu for his advises and improvements of manuscript.

\section{References}

Babaev, M. P., Gurbanov, E. A., \& Ramazanova, F. M. (2015). Main types of soil degradation in the Kura-Aras Lowland of Azerbaijan. Eurasian Soil Science, 48(4), 445-456.

Bajocco, S., Smiraglia, D., Scaglione, M., Raparelli, E., \& Salvati, L. (2018). Exploring the role of land degradation on agricultural land use change dynamics. Science of the Total Environment, 636, 1373-1381.

Baude, M., Meyer, B. C., \& Schindewolf, M. (2019). Land use change in an agricultural landscape causing degradation of soil based ecosystem services. Science of The Total Environment, 659, 1526-1536.

Bednáŕ, M., \& Šarapatka, B. (2018). Relationships between physical-geographical factors and soil degradation on agricultural land. Environmental Research, 164, 660-668.

Begum Nasir Ahmad, N. S., Mustafa, F. B., Yusoff, S. Y. M., \& Gideon, D. (2020). A systematic review of soil erosion control practices on the agricultural land in Asia. International Soil and Water Conservation Research.

Ferreira, C. dos R., Silva Neto, E. C. da, Pereira, M. G., Guedes, J. do N., Rosset, J. S., \& Anjos, L. H. C. dos. (2020). Dynamics of soil aggregation and organic carbon fractions over 23 years of No-till management. Soil and Tillage Research, 198, 104533.

Gabbasova, I. M., Suleimanov, R. R., Garipov, T. T., Komissarov, M. A., Sidorova, L. V., Galimzyanova, N. F., Liebelt, P., Abakumov, E. V., Gimaletdinova, G. A., \& Prostyakova, Z. G. (2018). The use of local fertilizers supplemented with Trichoderma koningii Oudem. At No-till vs. Conventional tillage of agrochernozem in Southern Ural. Agricultural Biology, 53(5), 1004-1012.

Gabbasova, I. M., Suleimanov, R. R., Khabirov, I. K., Komissarov, M. A., Fruehauf, M., Liebelt, P., Garipov, T. T., Sidorova, L. V., \& Khaziev, F. Kh. (2016). Temporal changes of eroded soils depending on their agricultural use in the Southern Cis-Ural region. Eurasian Soil Science, 49(10), 1204-1210.

Gabbasova, I. M., Suleimanov, R. R., Khabirov, I. K., Komissarov, M. A., Garipov, T. T., Sidorova, L. V., Asylbaev, I. G., Rafikov, B. V., \& Yaubasarov, R. B. (2015). Assessment of the agrochernozem status in Trans-Ural steppe under application of No-till management system. Russian Agricultural Sciences, 41(1), 34-39.

Gao, W., Whalley, W. R., Tian, Z., Liu, J., \& Ren, T. (2016). A simple model to predict soil penetrometer resistance as a function of density, drying and depth in the field. Soil and Tillage Research, 155, 190-198.

Govers, G., Van Oost, K., \& Wang, Z. (2014). Scratching the Critical Zone: The Global Footprint of Agricultural Soil Erosion. Procedia Earth and Planetary Science, 10, 313-318.

Gurbanov, E. A. (2010). Soil degradation due to erosion under furrow irrigation. Eurasian Soil Science, 43(12), 1387-1393.

Gürsoy, S., \& Türk, Z. (2019). Effects of land rolling on soil properties and plant growth in chickpea production. Soil and Tillage Research, 195, 104425.

Huang, R., Huang, J., Zhang, C., Ma, H., Zhuo, W., Chen, Y., Zhu, D., Wu, Q., \& Mansaray, L. R. (2020). Soil temperature estimation at different depths, using remotely-sensed data. Journal of Integrative Agriculture, 19(1), 277-290.

Kadilnikov I.P. (Ed). (1964). Physiographic Zoning of Bashkir ASSR. Bashkir State University Press, Ufa, Russia. (Ru). 
Khaziev F.Kh. (2012). Soils Ecology of Bashkortostan. Gilem Press, Ufa, Russia. (Ru). Khaziev F.Kh. (Ed). (1997). Soils of Bashkortostan. Vol. 2. Fertility Reproduction: Zonal and Ecological Aspects. Gilem Press, Ufa, Russia. (Ru).

Li, Fa-yong, Liang, X., Liu, Z., \& Tian, G. (2019). No-till with straw return retains soil total P while reducing loss potential of soil colloidal P in rice-fallow systems. Agriculture, Ecosystems \& Environment, 286, 106653.

Lin, L., He, Y., \& Chen, J. (2016). The influence of soil drying- and tillage-induced penetration resistance on maize root growth in a clayey soil. Journal of Integrative Agriculture, 15(5), $1112-1120$.

Luetzenburg, G., Bittner, M. J., Calsamiglia, A., Renschler, C. S., Estrany, J., \& Poeppl, R. (2020). Climate and land use change effects on soil erosion in two small agricultural catchment systems Fugnitz - Austria, Can Revull - Spain. Science of the Total Environment, 704, 135389.

Neugschwandtner, R. W., Száková, J., Pachtrog, V., Tlustoš, P., Černý, J., Kulhánek, M., Kaul, H.-P., Euteneuer, P., Moitzi, G., \& Wagentristl, H. (2020). Basic soil chemical properties after 15 years in a long-term tillage and crop rotation experiment. International Agrophysics, 34(1), 133-140.

Ni, J., Cheng, Y., Wang, Q., Ng, C. W. W., \& Garg, A. (2019). Effects of vegetation on soil temperature and water content: Field monitoring and numerical modelling. Journal of Hydrology, 571, 494-502.

Nowak, A., \& Schneider, C. (2017). Environmental characteristics, agricultural land use, and vulnerability to degradation in Malopolska Province (Poland). Science of the Total Environment, 590-591, 620-632.

Nunes, M. R., van Es, H. M., Schindelbeck, R., Ristow, A. J., \& Ryan, M. (2018). No-till and cropping system diversification improve soil health and crop yield. Geoderma, 328, 30-43.

Pacheco, F. A. L., Sanches Fernandes, L. F., Valle Junior, R. F., Valera, C. A., \& Pissarra, T. C. T. (2018). Land degradation: Multiple environmental consequences and routes to neutrality. Current Opinion in Environmental Science \& Health, 5, 79-86.

Pankova E.I. \& Novikova A.F. (2000). Soil degradation processes on agricultural lands of Russia. Eurasian Soil Science. 33, 319-330. (Ru).

Park, J.-H., Meusburger, K., Jang, I., Kang, H., \& Alewell, C. (2014). Erosion-induced changes in soil biogeochemical and microbiological properties in Swiss Alpine grasslands. Soil Biology and Biochemistry, 69, 382-392.

Paula, A. L. de, Giarola, N. F. B., de Lima, R. P., Wiecheteck, L. H., \& da Silva, A. P. (2020). Methodological aspects of the quantification of dispersible clay and their relations with soil properties along a catena under no-till system. International Agrophysics, 34(2), 273-280.

Piazza, G., Pellegrino, E., Moscatelli, M. C., \& Ercoli, L. (2020). Long-term conservation tillage and nitrogen fertilization effects on soil aggregate distribution, nutrient stocks and enzymatic activities in bulk soil and occluded microaggregates. Soil and Tillage Research, 196, 104482.

Radford, B. J., Yule, D. F., McGarry, D., \& Playford, C. (2007). Amelioration of soil compaction can take 5 years on a Vertisol under no till in the semi-arid subtropics. Soil and Tillage Research, 97(2), 249-255.

Sarapatka, B., Cap, L., \& Bila, P. (2018). The varying effect of water erosion on chemical and biochemical soil properties in different parts of Chernozem slopes. Geoderma, 314, 20-26.

Shein E.V. \& Karpachevskii L.O. (Eds). (2007). Theories and Methods in Soil Physics. Grif and K Press, Moscow, Russia. (Ru).

Sithole, N. J., \& Magwaza, L. S. (2019). Long-term changes of soil chemical characteristics and maize yield in no-till conservation agriculture in a semi-arid environment of South Africa. Soil and Tillage Research, 194, 104317.

Skaalsveen, K., Ingram, J., \& Urquhart, J. (2020). The role of farmers' social networks in the implementation of no-till farming practices. Agricultural Systems, 181, 102824.

Smetanová, A., Follain, S., David, M., Ciampalini, R., Raclot, D., Crabit, A., \& Le Bissonnais, Y. (2019). Landscaping compromises for land degradation neutrality: The case of soil erosion in a Mediterranean agricultural landscape. Journal of Environmental Management, 235, 282292. 
Travnikova, L. S., Artem'eva, Z. S., \& Sorokina, N. P. (2010). Distribution of the particle-size fractions in soddy-podzolic soils subjected to sheet erosion. Eurasian Soil Science, 43(4), 459-467.

Vanwalleghem, T., Gómez, J. A., Infante Amate, J., González de Molina, M., Vanderlinden, K., Guzmán, G., Laguna, A., \& Giráldez, J. V. (2017). Impact of historical land use and soil management change on soil erosion and agricultural sustainability during the Anthropocene. Anthropocene, 17, 13-29.

Vávra, J., Duží, B., Lapka, M., Cudlínová, E., \& Rikoon, J. S. (2019). Socio-economic context of soil erosion: A comparative local stakeholders' case study from traditional agricultural region in the Czech Republic. Land Use Policy, 84, 127-137.

Wilson, G. V., Zhang, T., Wells, R. R., \& Liu, B. (2020). Consolidation effects on relationships among soil erosion properties and soil physical quality indicators. Soil and Tillage Research, 198, 104550.

Yin, W., Chai, Q., Guo, Y., Fan, Z., Hu, F., Fan, H., Zhao, C., Yu, A., \& Coulter, J. A. (2020). Straw and plastic management regulate air-soil temperature amplitude and wetting-drying alternation in soil to promote intercrop productivity in arid regions. Field Crops Research, 249, 107758.

Zambon, I., Colantoni, A., Carlucci, M., Morrow, N., Sateriano, A., \& Salvati, L. (2017). Land quality, sustainable development and environmental degradation in agricultural districts: A computational approach based on entropy indexes. Environmental Impact Assessment Review, 64, 37-46. 